\title{
KARAKTERISASI DAN PENGUJIAN AKTIVITAS ANTIMIKROBA MINUMAN PROBIOTIK ANTANAN (Centella asiatica (L.))
}

\section{THE CHARACTERIZATION AND ANTIMICROBIAL ACTIVITY ASSAY OF ANTANAN (Centella asiatica (L.)) PROBIOTIC DRINK}

\author{
Wawan Agustina ${ }^{1}$, Feni Khoerunisa ${ }^{2}$, Taufik Rahman ${ }^{1}$, Lia Ratnawati ${ }^{1}$ \\ ${ }^{1}$ Pusat Penelitian Teknologi Tepat Guna-Lembaga Ilmu Pengetahuan Indonesia \\ Jl. KS. Tubun No. 5 Subang, Jawa Barat, 41213 \\ ${ }^{2}$ Universitas Islam Negeri Sunan Gunung Djati Bandung \\ Jl. A.H. Nasution No.105, Cipadung, Cibiru, Kota Bandung, Jawa Barat, 40614 \\ E-mail: wanwa03@gmail.com; wawan.sukaluyu@gmail.com
}

Diterima : 25-03-2019

Direvisi : 15-04-2019

Disetujui : 30-04-2019

\begin{abstract}
ABSTRAK
Antanan merupakan tanaman obat yang mengandung alkaloid, saponin, steroid, terpenoid, karbohidrat, dan gula pereduksi namun demikian pemanfaatannya masih belum banyak. Tujuan penelitian ini adalah mengetahui karakteristik minuman probiotik antanan dan mengetahui efektivitas minuman probiotik antanan sebagai antimikroba bagi bakteri Staphylococcus aureus dan Escherichia coli. Tahapan penelitian dilakukan dengan membuat minuman probiotik antanan dengan perlakuan variasi konsentrasi susu skim. Selanjutnya dilakukan karakterisasi terhadap bahan baku, jus antanan dan minuman probiotik antanan serta uji antimikroba dari minuman probiotik antanan. Hasil pengujian menunjukkan bahwa minuman probiotik antanan dengan konsentrasi susu skim $0 \%, 5 \%, 7 \%$, dan $9 \%$ memiliki kandungan lemak antara 0,024\% - 0,178\%, kadar protein 3,708\%-8,589\%, kadar abu $0,268 \%$ $0,738 \%$, dan total asam 0,403\% - 1,198\%. Hasil tersebut telah memenuhi standar SNI 2981:2009 tentang yoghurt. Hasil uji aktivitas antimikroba menunjukkan bahwa minuman probiotik antanan dapat menghambat pertumbuhan bakteri Staphylococcus aureus dan Escherichia coli.
\end{abstract}

Kata kunci : Antanan, antimikroba, Escherichia coli, Staphylococcus aureus, minuman probiotik

\section{ABSTRACT}

Antanan are medicinal plants which contain alkaloids, saponins, steroids, terpenoids, carbohydrates, and reducing sugars. But, on the other hand, the use of them are rarely utilized. The purposes of this research were to determine the characteristics of antanan probiotic drink and examine the effectiveness of antanan probiotic as an antimicrobial for the Staphylococcus aureus and Escherichia coli. Steps of this research were the making of antanan probiotic drink with skim milk concentration variation treatment, characterization of the raw materials and antanan probiotic, and antimicrobial test of antanan probiotic. The results showed that antanan probiotic with a concentration of skim milk 5\%, 7\%, and $9 \%$ had a fat content of between $0.024 \%-0.178 \%$, protein content of $3.708 \%-8.589 \%$, ash content of $0.544 \%-0.738 \%$, and the total acid of $0.951 \%-1.198 \%$. These results were met with National Standard of Indonesia (SNI 2981:2009) about Yoghurt. The test results of antimicrobial activity showed that antanan probiotic can inhibit the growth of bacteria Staphylococcus aureus and Escherichia coli.

Keywords : Antanan, antimicrobial, Escherichia coli, Staphylococcus aureus, probiotic drink

88 Wawan Agustina, Feni Khoerunisa, Taufik Rahman, Lia Ratnawati Karakterisasi dan Pengujian Aktivitas Antimikroba Minuman Probiotik Antanan (Centella asiatica (L.)) 


\section{PENDAHULUAN}

$\mathrm{T}$

anaman antanan (Centella asiatica L.) merupakan tanaman tahunan yang tumbuh di daerah tropis dan subtropis dengan daerah penyebarannya yang luas. Di Indonesia sendiri tanaman antanan banyak digunkan sebagai obat tradisional sejak zaman dahulu (Herlina, 2010). Selain sebagai obat, tanaman ini banyak dimanfaatkan sebagai sayuran segar dan lalapan. Bagian tanaman antanan yang berkhasiat obat adalah daun, akar dan batang. Di Masyarakat, secara turun temurun antanan telah banyak dimanfaatkan sebagai tanaman obat baik digunakan dalam bentuk segar, dikeringkan atau diolah dalam bentuk jamu atau ramuan.

Tanaman antanan mengandung banyak senyawa aktif yang dapat memberikan manfaat kesehatan. Tanaman ini juga sejak lama telah banyak digunakan untuk tujuan pengobatan dan sebagai bahan kosmetik (James dan Ian, 2010). Pengobatan dengan menggunakan antanan diantaranya ialah untuk penyembuhan luka, gangguan mental, dan pengobatan penyakit kulit seperti leprosy dan psioriasis (Udoh et al., 2012). Tanaman antanan juga dapat memiliki potensi untuk digunakan sebagai antidiabet (Rahman et al. 2011a, dan Rahman et al., 2011b) dan memiliki aktivitan anti-hyperglycemic (Kabir et al., 2014). Selain sebagai tanaman obat antanan juga banyak digunakan sebagai bahan makanan baik dalam bentuk lalapan segar atau dimasak terlebih dahulu (Levi, 2015). Produk olahan antanan antara lain keripik daun (Levi, 2015), teh herbal dan jus (Rahman, 2011b), dan sambal atau disebut Sambai on peugaga (Mahyiddin, 2014).

Pemanfaatan antanan sebagai bahan pangan juga tidak terlepas dari nilai gizi yang dikandungnya. Menurut Arsyaf (2012), kandungan zat gizi yang terdapat pada daun antanan segar dalam basis kering adalah sebagai berikut $79,63 \%$ air; $22,5 \%$ protein; $6,3 \%$ lemak; $1,0 \%$ abu; $59,2 \%$ karbohidrat; 3,2\% asam asiatik; 388,5mg/100g vitamin C; 435,7ppm $\beta-$ karoten; $212,4 \mathrm{mg} / 100 \mathrm{~g}$ zat besi; $9.790,3 \mathrm{mg} / 100 \mathrm{~g}$ kalsium; dan 22,3mg/100g selenium.

Dewasa ini pemanfaatan antanan sebagai bahan pangan lebih bertujuan untuk meningkatkan nilai kesehatan atau lebih dikenal sebagai bahan pangan fungsional.

Namun demikian, pemanfaatan antanan sebagai bahan pangan sebenarnya lebih pada nilai fungsionalnya. Salah satu jenis pangan yang bernilai fungsional diantaranya ialah produk probiotik baik berupa makanan maupun minuman yang umumnya dibuat melalui proses fermentasi menggunakan mikroorganisme tertentu. Produk probiotik dapat didefinisikan sebagai produk berbahan dasar susu yang difermentasi menggunakan kultur mikroba dari jenis bakteri asam laktat (Anadon et al., 2016). Menurut Havenar (1992), probiotik adalah kultur mikroba hidup baik dalam bentuk tunggal maupun campuran yang dikonsumsi oleh manusia atau hewan dan dapat memberikan manfaat kesehatan utamanya yang berkaitan dengan sistem pencernaan.

Proses pembuatan minuman probiotik melibatkan bakteri asam laktat. Beberapa bakteri asam laktat yang dapat digunakan dalam pembuatan minuman probiotik yaitu Lactobacillus acidophilus, Lactobacillus casei Shirota, Bifidobacterium bifidum, Lactobacillus gasseri, Lactobacillus reuteri, Streptococcus thermophilus, Lactobacillus bulgaricus, Lactococcus lactis, Latococcus cremoris, dan Lactococcus diacetylactis (Setioningsih et al., 2004). Menurut Robinson et al., (1999), beberapa manfaat kesehatan dari konsumsi minuman probiotik diantaranya ialah dapat meningkatkan fungsi saluran pencernaan, mengurangi bakteri jahat dalam saluran pencernaan, menormalkan kerja usus besar dan beberapa fungsi lainnya.

Kualitas tekstur minuman probiotik yoghurt dari susu nabati dapat dipengaruhi oleh beberapa faktor seperti kandungan protein dalam susu nabati 3,5-4,0\%, jumlah starter yang digunakan tidak terlalu banyak, inokulasi starter dilakukan saat temperatur susu nabati sekitar $47^{\circ} \mathrm{C}$, pH tidak kurang dari 4,0 dan mengandung sekitar $0,75 \%$ asam laktat (Shurtleff dan Aoyagi, 1984). 
Beberapa minuman probiotik nabati telah banyak dibuat yaitu diantaranya minuman probiotik dari susu nabati kacang hijau (Agustina dan Andriana, 2010), minuman probiotik dari campuran ekstrak kedelai dan buncis dan disebut dengan istilah soy-yamgurt (Rusmarilin et al., 2018), minuman probiotik dari umbi bit (Panghal et al., 2017), dan minuman probiotik dari herbal mate (Ilex paraguariensis A.St.-Hil.) yang memiliki beberapa keuntungan yaitu dapat diklaim sebagai produk organik, mengandung kafein, fito-stimulan, dan senyawa antioksidan (Lima et al., 2012).

Berdasarkan pada informasi-informasi terkait manfaat dan kandungan senyawa penting yang terdapat pada antanan ini, maka dipandang perlu dilakukan penelitian untuk diversifikasi produk berbasis antanan. Hal ini agar produk berbasis antanan dapat lebih mudah dijangkau oleh masyarakat dalam varian produk yang dapat diterima dengan baik. Salah satu jenis produk berbasis antanan yang memiliki potensi yaitu minuman probiotik. Tujuan penelitian ini adalah untuk mengetahui karakteristik dan aktivitas antimikroba minuman probiotik antanan terhadap Staphylococcus aureus dan Escherichia coli.

\section{METODE PENELITIAN}

\section{Bahan dan Alat}

Bahan baku yang digunakan pada penelitian ini yaitu tanaman antanan (Centella asiatica L.) yang diperoleh dari pasar tradisional kota Subang. Sedangkan bahan pendukung yang digunakan antara lain susu skim, starter dari produk yoghurt plain komersial yang mengandung bakteri Streptococcus thermophilus dan Lactobacillus bulgaricus, gula pasir, madu komersial dan CMC. Bahan kimia yang digunakan untuk analisa antara lain akuades, plate count agar (Merck, Jerman), $\mathrm{HCl}$ (Merck, Jerman), n-heksana (Merck, Jerman), $\mathrm{NaOH}$ (Merck, Jerman), $\mathrm{CH}_{3} \mathrm{COOH}$ (Merck, Jerman), Kalium Iodida (Merck, Jerman), dan $\mathrm{H}_{2} \mathrm{SO}_{4}$ (Merck, Jerman). Bakteri Eschericia coli dan Staphylococcus aureus diperoleh dari Laboratorium Mikrobiologi, Sekolah Ilmu dan Teknologi Hayati, Institut Teknologi Bandung.

Peralatan yang digunakan antara lain blender, baskom, gelas ukur, timbangan analitik, saringan stainless, kain saring, panci dan kompor. Selain itu juga digunakan alat gelas (glassware), autoklaf, laminar air flow, mikropipet, tip, neraca analitik dan inkubator.

Pelaksanaan penelitian ini diawali dengan pembuatan jus antanan. Jus antanan yang dihasilkan selanjutnya digunakan untuk pembuatan minuman probiotik antanan. Penelitian dilakukan dengan perlakuan variasi konsentrasi susu skim dengan 4 taraf yaitu $0 \%(P 1), 5 \%$ (P2), 7\%(P3) dan 9\%(P4). Jumlah inokulum yang ditambahkan masing-masing sebanyak $10 \%$. Setiap perlakuan di buat dalam 2 erlenmeyer (duplo) dan diinkubasi selama 18 jam di dalam inkubator pada suhu $37^{\circ} \mathrm{C}$.

\section{Analisis}

Sampel yang dianalisa meliputi tanaman antanan segar, jus antanan dan minuman probiotik antanan. Analisa yang dilakukan terhadap sampel tanaman antanan segar dan jus adalah analisa proksimat yang meliputi air, abu, lemak, protein dan karbohidrat bydifference. Sedangkan analisa sampel minuman probiotik antanan meliputi proksimat dan total asam tertitrasi. Analisa proksimat (air, abu, lemak, protein, karbohidrat by difference) dan total asam tertitrasi menggunakan metode SNI 01-2891-1992 tentang cara uji makanan dan minuman (BSN, 1992). Sedangkan pengujian antimikroba menggunakan metode difusi agar (Elumalai et al., 2011).

\section{Proses Pembuatan Minuman Probiotik Antanan}

Proses pembuatan minuman probiotik yaitu, mula-mula antanan dicuci bersih, dipilih daun, batang dan akar yang baik. Kemudian bagian yang telah disortir dicacah dan diblender 
dengan perbandingan $1: 3$ untuk antanan dan air. Antanan halus disaring dengan saringan stainless, kemudian di saring kembali dengan kain saring. Selanjutnya sari antanan ditambah dengan susu skim dan CMC, kemudian diaduk menggunakan blender. Sari antanan kemudian dipanaskan, lalu ditambahkan gula dan dibiarkan hingga suhu $80^{\circ} \mathrm{C}$. Kemudian ditambahkan madu dan distabilkan pada suhu $80^{\circ} \mathrm{C}$ selama 15 menit. Setelah pasteurisasi kemudian jus didinginkan sampai suhu kira-kira $35-37^{\circ} \mathrm{C}$. Setelah dingin sampel dipindahkan ke dalam ruang steril untuk diinokulasi dengan bibit yoghurt. Setelah penambahan starter botol-botol kembali ditutup rapat dan tutupnya dilapisi dengan plastik. Campuran sari antanan kemudian diinkubasi dalam inkubator pada suhu $37^{\circ} \mathrm{C}$ selama 18 jam. Setelah proses fermentasi sampel selanjutnya dikarakterisasi dan diuji aktivitas antimikrobanya.

\section{HASIL DAN PEMBAHASAN}

\section{Karakterisasi Bahan Baku}

Karakterisasi bahan baku dilakukan terhadap tanaman dan jus antanan. Hasil pengujian ditampilkan pada Tabel 1. Berikut ini:

Tabel 1. Analisis proksimat tanaman dan jus antanan (Centella asiatica L.)

\begin{tabular}{clccc}
\hline No & Kriteria Uji & Satuan & Tanaman Antanan & Jus Antanan \\
\hline 1 & Air & $\%$ & 82,88 & 87,94 \\
\hline 2 & Karbohidrat & $\%$ & 2,20 & 6,03 \\
\hline 3 & Protein & $\%$ & 2,23 & 0,56 \\
\hline 4 & Lemak & $\%$ & 0,27 & 0,18 \\
\hline 5 & Kadar Abu & $\%$ & 1,00 & tidak diuji \\
\hline
\end{tabular}

Berdasarkan hasil pengujian diketahui bahwa tanaman antanan segar memiliki kandungan sekitar $82,88 \%$ air, 2,23\% protein, 2,2\% karbohidrat, 0,27\% lemak dan $1 \%$ abu. Menurut Pramono (1992), dalam setiap $100 \mathrm{~g}$ daun antanan mengandung 89,3 g air; 1,6 g protein; 0,6 g lemak; 6,9 g karbohidrat; selain itu masih mengandung komponen gizi lainnya seperti serat, vitamin dan mineral 2,0 (Kristina et al., 2009). Menurut Joshi dan Chaturvedi (2013), antanan memiliki kandungan air sekitar 84,6\%, kadar protein 2,4\% dan serat 5,92\%. Jika dibandingkan antara nilai hasil pengujian dengan beberapa hasil penelitian lain tersebut di atas ternyata relatif berbeda, namun demikian perbedaan ini bisa dimaklumi karena nilai tersebut dapat dipengaruhi oleh banyak faktor. Menurut Dalimartha dan Adrian (2013), kandungan kimiawi tanaman obat sangat bervariasi karena dipengaruhi oleh banyak faktor seperti lingkungan tempat tumbuh, hara tanah, iklim, ketinggian, kualitas bibit teknologi budidaya,umur tanaman, cara penanganan pascapanen dan penyimpanan.

Sedangkan untuk jus antanan yang telah diberi campuran gula, madu, dan CMC sebelum ditambah susu skim mengandung 87,94 \% air, 6,03 \% karbohidrat, 0,56 \% protein, dan 0,18 $\%$ lemak. Kandungan nutrisi seperti protein, karbohidrat dan lemak pada jus antanan menjadi lebih rendah dibandingkan kandungan di dalam tanamannya sendiri. Hal tersebut dapat diakibatkan oleh adanya pengenceran (penambahan air) dan pencampuran bahan lainnya yang mengakibatkan penurunan konsentrasi nutrisi pada jus yang dibuat. Belum ditemukan data pembanding untuk produk jus antanan

\section{Karakterisasi Minuman Probiotik Antanan (MPA)}

Karakterisasi sampel minuman probiotik antanan meliputi kadar air dan beberapa parameter yang dipersyaratkan dalam SNI 2981:2009 tentang yoghurt. Kadar air sampel minuman probiotik antanan dengan penambahan susu skim $0 \%, 5 \%, 7 \%$, dan $9 \%$ masing 
masing sebesar $89,11 \%, 85,71 \%, 84,38 \%$ dan 73,24\%. Sedangkan hasil karakterisasi minuman probiotik antanan yang mengacu pada SNI dapat dilihat pada Tabel 2.

Tabel 2. Karakteristik minuman probiotik antanan (Centella asiatica L.)

\begin{tabular}{|c|c|c|c|c|c|c|c|}
\hline No & Kriteria Uji & Satuan & SNI 2981:2009 & MPA $0 \%$ & MPA $5 \%$ & MPA $7 \%$ & MPA $9 \%$ \\
\hline \multirow[t]{4}{*}{1} & Keadaan & & & & & & \\
\hline & 1.1 Penampakan & & $\begin{array}{c}\text { Cairan } \\
\text { Kental s/d } \\
\text { Semi Padat }\end{array}$ & Cairan & $\begin{array}{l}\text { Cairan } \\
\text { Sedikit } \\
\text { Kental }\end{array}$ & $\begin{array}{l}\text { Cairan } \\
\text { Kental }\end{array}$ & $\begin{array}{l}\text { Cairan } \\
\text { Kental }\end{array}$ \\
\hline & 1.2 Bau & & Normal/Khas & $\begin{array}{l}\text { Normal/ } \\
\text { Khas }\end{array}$ & $\begin{array}{c}\text { Normal/ } \\
\text { Khas }\end{array}$ & $\begin{array}{l}\text { Normal/ } \\
\text { Khas }\end{array}$ & $\begin{array}{c}\text { Normal/ } \\
\text { Khas }\end{array}$ \\
\hline & 1.3 Konistensi & & Homogen & Homogen & Homogen & Homogen & Homogen \\
\hline 2 & Abu & $\%$ & Maks 1.0 & 0,27 & 0,54 & 0,66 & 0,74 \\
\hline 3 & Protein & $\%$ & Min 2,7 & 3,71 & 5,48 & 6,24 & 8,59 \\
\hline 4 & Lemak & $\%$ & 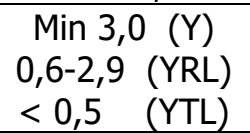 & 0,02 & 0,10 & 0,12 & 0,18 \\
\hline 5 & $\begin{array}{l}\text { Keasaman (Asam } \\
\text { Laktat) }\end{array}$ & $\%$ & $0,5-2,0$ & 0,40 & 0,95 & 1,13 & 1,20 \\
\hline
\end{tabular}

Ket : MPA - \% = Minuman probiotik antanan dengan persentase penambahan susu skim

\section{Kadar Air}

Berdasarkan hasil pengujian diketahui bahwa kadar air mengalami penurunan seiring dengan penambahan susu skim pada sampel minuman probiotik antanan. Minuman probiotik antanan kontrol (tanpa penambahan susu skim) memiliki nilai kadar air tertinggi yaitu $89,11 \%$, sedangkan minuman probiotik dengan penambahan susu skim $9 \%$ memiliki nilai kadar air terendah yaitu $73,24 \%$. Penurunan kadar air ini diduga dipengaruhi oleh semakin banyaknya padatan kering yang ditambahkan yaitu susu skim. Pada penelitian lain juga diketahui produk yoghurt nabati kacang hijau kadar airnya semakin berkurang dengan semakin meningkatnya jumlah karagenan yang ditambahkan (Darmajana, 2011).

\section{Keadaan}

Berdasarkan pengamatan secara visual terhadap keadaan sampel, dari penampakannya terlihat bahwa sampel dengan penambahan susu skim memiliki gumpalan berwarna coklat kehijauan, dan jika diaduk akan menjadi cairan kental yang homogen. Semakin tinggi konsentrasi susu skim maka semakin kuat aroma asam yang tercium. Hal ini menunjukkan adanya aktivitas bakteri asam laktat dalam memanfaatkan substrat susu skim yang ditambahkan selama proses fermentasi. Bakteri asam laktat pada starter yoghurt yang ditambahkan mengubah laktosa yang terdapat pada susu skim menjadi asam laktat yang menimbulkan aroma asam. Dari Tabel 2. di atas diketahui bahwa secara keseluruhan sampel telah memenuhi kriteria yoghurt susu hewani berdasarkan SNI 2981:2009 tentang parameter mutu yoghurt.

\section{Kadar Abu}

Kadar abu pada minuman probiotik antanan pada penelitian ini telah memenuhi kriteria SNI 2981:2009 tentang parameter mutu yoghurt yaitu berkisar antara 0,27-0,74\%.Dari Tabel 2 menunjukkan bahwa semakin tinggi persentase susu skim yang ditambahkan semakin tinggi pula kadar abu sampel. Kadar abu menyatakan persentase kandungan mineral yang terkandung dalam suatu bahan. Nilai kadar abu pada penelitian ini hampir sama dengan penelitian lain mengenai yoghurt nabati dari sawo dan kacang hijau. Kadar abu yoghurt sawo adalah sebesar 0,44-0,97\% (Wanita et al., 2017) dan kadar abu yoghurt nabati kacang hijau sebesar 0,61\% (Agustina dan Andriana, 2010). 


\section{Kadar Protein}

Produk jus antanan memiliki kandungan protein sebesar 0,56\%. Tetapi ketika jus antanan di buat menjadi minuman probiotik antanan, protein kembali naik dan memiliki nilai diatas nilai minimum parameter mutu yoghurt. Tingginya kadar protein dari minuman probiotik tersebut berasal dari susu skim yang ditambahkan. Dapat dilihat bahwa semakin tinggi konsentrasi susu skim yang ditambahkan maka semakin tinggi pula kadar protein yang dimiliki oleh produk minuman tersebut. Pada beberapa yoghurt nabati lainnya diketahui yoghurt sawo dengan penambahan kasein sampai dengan $15 \%$ memiliki kandungan protein sekitar 1.55 - 3,40\% (Wanita et al., 2017). Pada yoghurt nabati kacang hijau dengan penambahan susu skim 9\% memiliki kandungan protein sekitar 2,12\% (Agustina dan Andriana, 2010). Peningkatan protein selain dipengaruhi oleh penambahan substrat susu skim, juga dimungkinkan dipengaruhi oleh semakin banyaknya jumlah bakteri asam laktat yang tumbuh dan berkembang. Di mana komposisi penyusun sel dari bakteri asam laktat tersebut juga mengandung protein (Wanita et al., 2017).

\section{Kadar Lemak}

Tabel 2 memperlihatkan bahwa kadar lemak dari sampel uji sangat rendah yaitu berkisar antara 0,02-0,18\%. Jika mengacu pada standar SNI 2981:2009 tentang parameter mutu yoghurt, maka minuman probiotik antanan ini dapat dikategorikan ke dalam kelompok yoghurt tanpa lemak (YTL), yaitu yoghurt dengan kandungan lemak maksimal 0,5\%. Yoghurt sawo dengan penambahan kasein sampai $15 \%$ memiliki kandungan lemak yang hampir sama yaitu sekitar 0,09-0,17\% (Wanita et al., 2017). Yoghurt nabati kacang hijau dengan penambahan 9\% kasein memiliki kandungan lemak sekitar 0,3\% (Agustina dan Andriana, 2010).

\section{Keasaman (Asam Laktat)}

Nilai keasaman yang dihitung sebagai asam laktat dari minuman probiotik antanan pada ketiga jenis sampel dengan penambahan susu skim 5\%, 7\%, dan 9\% sesuai dengan syarat mutu SNI 2981:2009 tentang parameter mutu yoghurt. Semua sampel diberi tambahan starter sebanyak $10 \%$ dari jumlah jus yang digunakan yaitu $6 \mathrm{ml}$ starter. Pada produk fermentasi berbasis susu, asam laktat umumnya dihasilkan dari aktivitas metabolisme oleh bakteri asam laktat seperti Lactobaccilus bulgaris dan Streptococcus thermophiles yang dikonversi dari laktosa sebagai sumber karbon utamanya.

Pada sampel MPA 5\%, MPA 7\%, dan MPA 9\% ditambahkan susu skim sebagai sumber laktosa sehingga proses fermentasi mikroorganisme lebih maksimal. Sedangkan pada konsentrasi MPA 0\% tidak diberi tambahan susu skim sehingga mikroorganisme probiotik tidak dapat berkembang dengan baik. Yoghurt nabati kacang hijau dengan penambahan 9\% susu skim memiliki jumlah asam sekitar 1,47\% (Agustina dan Andriana, 2010). Sedangkan hasil penelitian Agustina dan Rahman (2010) menunjukkan bahwa yoghurt kacang hijau dengan penambahan $9 \%$ skim milk dan $5 \%$ sukrosa memiliki total asam sebesar $0,7 \%$. Yoghurt nabati kacang hijau tanpa penambahan karagenan dan dengan penambahan karagenan 1,5\% masing masing memiliki total asam sebesar 1,54 dan 1,29\% (Darmajana, 2011). Yoghurt dari sari kedelai dengan lama fermentasi 15 jam memiliki kandungan asam laktat berkisar antara 0,35 - 0,45\% (Zainuddin, 2014).

Bakteri asam laktat seperti Lactobaccilus bulgaris dan Streptococcus thermophilus dapat memanfaatkan sumber karbon lain pada jus antanan yang telah di tambahkan gula dan madu, namun untuk menghasilkan minuman probiotik dengan kandungan asam yang tinggi terutama asam laktat, maka ditambahkan laktosa yang berasal dari susu skim. Hal ini sesuai dengan penelitian Agustina dan Andriana (2010) pada pembuatan yoghurt dari susu nabati kacang hijau. Nilai keasaman yang dihitung sebagai asam laktat merupakan salah satu indikator penting yang harus diuji pada penelitian pembuatan yoghurt. Hal ini karena asam laktat merupakan salah satu senyawa penting yang diharapkan dari proses pembuatan yoghurt sebagai minuman probiotik (Agustina dan Andriana, 2010). Marshall (1992) dalam Askar et 
al., (2005) mengungkapkan bahwa kandungan asam dalam yoghurt merupakan produk utama yang dapat menjadikan ciri khas yoghurt dan yoghurt yang baik mengandung 0,85-0,95\% total asam.

Dasar fermentasi susu pada proses pembuatan yoghurt adalah perombakan senyawa gula terutama laktosa yang dikonversi menjadi asam laktat. Asam laktat yang dihasilkan dapat meningkatkan keasaman dan memberi citarasa yang khas dari produk fermentasi. Meningkatnya keasaman juga berperan dalam proses penghambatan aktivitas mikroorganisme patogen dan perusak susu, sehingga dapat meningkatkan keawetan susu (Winarno, 2003).

\section{Pengujian Antimikroba}

Pengujian antimikroba dilakukan dengan metode difusi agar dengan masa inkubasi pertama selama 24 jam pada suhu $37^{\circ} \mathrm{C}$, dan diamati selama 4 hari berturut-turut. Parameter yang diamati adalah diameter dalam dan diameter luar. Diameter dalam merupakan zona bening yang berada di dekat paperdisc sedangkan diameter luar merupakan zona bening yang berada di bagian terluar lingkaran putih.

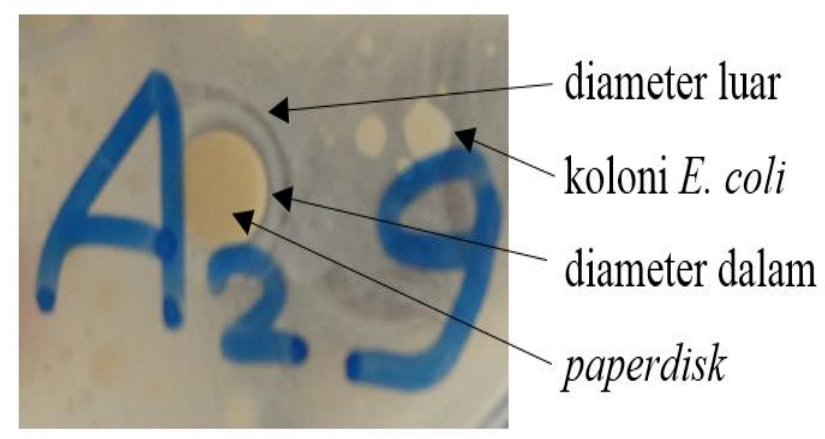

Gambar 1. Hasil pengujian aktivitas antimikroba minuman probiotik antanan (Centella asiatica L.) konsentrasi $9 \%$ terhadap bakteri E. coli.

Dari hasil pengujian anti bakteri ini memperlihatkan bahwa untuk keseluruhan sampel yang di uji pada bakteri patogen dapat membentuk zona bening di area dalam dengan perbedaan ukuran yang tidak terlalu signifikan. Begitu pula pada pembentukan diameter luar, semua sampel masih dapat membentuk zona bening meskipun pembentukan zona bening tersebut terjadi di hari ke 3 dan 4 saja. Sampel MPA 5\% merupakan sampel paling baik untuk menghambat pertumbuhan bakteri $S$. aureus yaitu dengan ukuran diameter hambat bagian dalam $0,75 \mathrm{~cm}$ dan bagian luar $1,13 \mathrm{~cm}$. Sedangkan untuk bakteri $E$. coli, zona hambat diameter dalam terbaik ditunjukkan oleh sampel MPA $5 \%$ yaitu $0,81 \mathrm{~cm}$, namun untuk zona hambat diameter luar terbaik ditunjukkan oleh sampel MPA $7 \%$ yaitu $1,44 \mathrm{~cm}$.

Tabel 3. Hasil uji aktivitas antimikroba minuman probiotik antanan (Centella asiatica L.)

\begin{tabular}{lcccc}
\hline Sampel & \multicolumn{2}{c}{ S. aureus } & \multicolumn{2}{c}{ E. coli } \\
\hline & \multicolumn{2}{c}{ Diameter zona bening $(\mathrm{cm})$} & \multicolumn{2}{c}{ Diameter zona bening (cm) } \\
\hline MPA 0\% & Dalam & Luar & Dalam & Luar \\
\hline MPA 5 \% & 0,740 & 1,125 & 0,755 & 1,100 \\
\hline MPA 7\% & 0,745 & 1,125 & 0,810 & 1,356 \\
\hline MPA 9\% & 0,735 & 1,058 & 0,770 & 1,438 \\
\hline
\end{tabular}

Ket : Nilai zona bening merupakan nilai rata-rata dari 5 kali pengukuran 
Dari hasil pengujian tersebut disimpulkan bahwa minuman probiotik antanan berpotensi lebih baik dibandingkan dengan ekstrak etanol antanan (antanan) yang hanya dapat bereaksi optimal pada bakteri gram positif. Minuman probiotik antanan dapat menghambat pertumbuhan bakteri $E$. coli dan $S$. aureus yang bahkan tidak dapat di hambat oleh ekstrak etanol antanan. Menurut Rachmawati et.al. (2011), ekstrak etanol dari tanaman antanan yang yang diperoleh dari fraksi kloroform diketahui dapat berperan sebagai antibakteri untuk spesies Bacillus subtilis dan Pseudomonas aeruginosa yang merupakan kelompok bakteri gram positif, namun tidak berperan untuk menghambat pertumbuhan bakteri $S$. aureus, $E$. coli dan S. typhi yang merupakan kelompok bakteri gram negatif.

Berdasarkan hal tersebut menunjukkan bahwa larutan uji lebih mudah menghambat bakteri gram positif dibandingkan bakteri gram negatif, artinya bakteri gram positif lebih rentan terhadap senyawa-senyawa kimia dibandingkan gram negatif. Hal ini kemungkinan disebabkan oleh perbedaan komposisi dan struktur dinding sel pada bakteri gram positif dan gram negatif. Sebagaimana diketahui bahwa struktur dinding sel bakteri gram positif relatif lebih sederhana dibandingkan struktur dinding bakteri gram negatif yang lebih kompleks. Menurut Jawetz et.al. (2005), struktur dinding sel bakteri gram positif berupa lapisan tunggal dengan komposisi lipid yang relatif rendah yaitu sekitar $1-4 \%$, sedangkan struktur dinding sel bakteri gram negatif terdiri dari tiga lapisan yaitu lapisan luar (lipoprotein), lapisan tengah (lipopolisakarida), dan lapisan dalam (peptidoglikan) dengan komposisi lipid sekitar $11-12 \%$. Oleh karena itu dinding sel bakteri gram positif lebih mudah ditembus oleh senyawa aktif yang berasal dari ekstrak tanaman. Menurut Rachmawati et.al. (2011), bahwa berdasarkan hasil penelitiannya diketahui beberapa senyawa aktif yang terdapat dalam fraksi kloroform ekstrak etanol adalah kelompok fenol dan terpenoid. Sehingga sangat dimungkinkan bahwa senyawa tersebutlah yang dapat berperan sebagai antimikroba.

Mekanisme penghambatan pertumbuhan mikroba oleh senyawa fenol dapat terjadi berdasarkan konsentrasi senyawa tersebut dalam media yang ada. Pada konsentrasi yang rendah fenol dapat merusak membran sel dan menyebabkan kebocoran inti sel. Sedangkan pada konsentrasi yang tinggi akan menyebabkan terjadinya koagulasi antara fenol dengan protein seluler. Proses perusakan akan berperan secara efektif utamanya pada saat terjadinya pembelahan sel (Volk dan Wheller, 1984). Adapun terpenoid dapat berperan sebagai anti bakteri dengan cara bereaksi membentuk ikatan polimer dengan protein transmembran (porin) sehingga porin tidak berfungsi. Porin itu sendiri merupakan bagian yang berperan dalam proses masuknya nutrisi ke dalam sel. Dengan rusaknya porin maka asupan nutrisi menjadi terhambat dan menyebabkan kematian sel (Cowan, 1999).

\section{KESIMPULAN}

Minuman probiotik antanan dengan konsentrasi susu skim 5\%,7\%, dan $9 \%$ memiliki kandungan lemak antara 0,10\% s/d 0,18\%, protein 5,48\% s/d 8,59\%, abu 0,54\% s/d 0,74\%, dan total asam 0,95\% s/d 1,20\% yang telah memenuhi kriteria berdasarkan SNI 01-29811992 tentang parameter mutu yoghurt.

Minuman probiotik antanan juga memiliki kemampuan untuk menghambat pertumbuhan bakteri $E$. coli dan $S$. aureus ditandai dengan adanya zona bening yang terbentuk di sekitar paperdisc. MPA 5\% merupakan konsentrasi paling baik untuk menghambat pertumbuhan bakteri $S$. aureus dengan ukuran diameter hambat bagian dalam 0,75 cm dan diameter bagian luar $1,13 \mathrm{~cm}$. Sedangkan untuk bakteri $E$. coli, MPA 5\% memberikan diameter hambat bagian dalam terbaik yaitu $0,81 \mathrm{~cm}$, namun untuk zona hambat diameter luarnya ditunjukkan oleh MPA 7\% yaitu sebesar $1,44 \mathrm{~cm}$ untuk E.coli. 


\section{UCAPAN TERIMAKASIH}

Penulis ingin menyampaikan terimakasih pada berbagai pihak yang telah membantu dan terlibat pada proses penelitian terkait pembuatan minuman probiotik antanan.

\section{DAFTAR PUSTAKA}

Agustina W, Rahman T. Pengaruh Variasi Konsentrasi Sukrosa dan Susu Skim Terhadap Jumlah Asam sebagai Asam Laktat Yoghurt Kacang Hijau (Phaseolus radiates L). Prosiding Seminar Nasional Teknik Kimia "Kejuangan". UPN "Veteran" Yogyakarta. 2010 : B08 1 B08 6.

Agustina W, Andriana Y. Karakterisasi Produk Yoghurt Susu Nabati Kacang Hijau (Phaseolus radiatus L.). Prosiding Seminar Nasional Teknik Kimia "Kejuangan.UPN "Veteran" Yogyakarta. 2010: D07 1 - D07 5.

Anadón A, María RML, Irma A, María AM. Nutraceuticals: Efficacy, Safety and Toxicity. Probiotics: Safety and Toxicity Considerations (Chapter 55). Academic Press is an imprint of Elsevier. 2016. ISBN: 978-0-12-802147-7.

Arsyaf AR. Pembuatan Roti Kering (Bagelen) Antanan (Centella asiatica) Sebagai Pangan Fungsional Untuk Lansia. Skripsi. Departemen Gizi Masyarakat Fakultas Ekologi Manusia. Institut Pertanian Bogor. 2012.

Askar S, Sugiarto. Uji Kimiawi dan Organoleptik Sebagai Uji Mutu Yoghurt. Prosiding Temu Teknis Nasional Tenaga Fungsional Pertanian. Balai Penelitian Ternak dan Balai Besar Pasca Panen Pertanian. Bogor. 2005 : 108 - 113.

Badan Standardisasi Nasional. Standar Nasional Indonesia 01-2891-1992. Cara Uji Makanan dan Minuman. Jakarta: Badan Standardisasi Nasional; 1992.

Badan Standardisasi Nasional. Standar Nasional Indonesia 2981:2009. Yoghurt. Jakarta: Badan Standardisasi Nasional; 2009.

Cowan, M. Plant Product as Antimicrobial Agent. Clinical Microbiology Reviews. 1999; 12 (4): 564-582

Dalimartha S, Andrian. Ramuan Herbal Tumpas Penyakit. Jakarta : Penebar Swadaya. 2013

Darmajana D. Pengaruh Konsentrasi Starter dan Konsentrasi Karagenan terhadap Mutu Yoghurt Nabati Kacang Hijau. Prosiding SNaPP2011 Sains, Teknologi, dan Kesehatan. 2011; 2 (1) : 267-274.

Elumalai EK, Ramachandran M, Thirumalai T, Vinothkumar P. Antibacterial activity of various leaf extracts of Merremia emarginata. Asian Pac J Trop Biomed. 2011; 1(5): 406-408.

Havenar, R. Selection of Probiotics Use. Dalam: Fuller R. Editor. Probiotics: The Scientific Basis. London: Chapman \& Hall; 1992: 225-259.

Herlina. Pengaruh Triterpen Total Pegagan (Centella asiatica (L) Urban) terhadap Fungsi Kognitif Belajar dan Mengingat pada Mencit Jantan Albino (Mus musculus). Jurnal Penelitian Sains. Edisi Khusus Juni. 2010 (C) 10:06-06: 21-24.

James JT, Dubery, IA. Pentacyclic Triterpenoids from the Medicinal Herb, Centella asiatica (L.) Urban. Molecules. $2009 ; 14: 3922-3941$.

Jawetz E, Melnick JL, Adelberg E.Mikrobiologi Kedokteran, Penerjemah dan editor Bagian Mikrobiologi Kedokteran Universitas Airlangga, Jakarta : Penerbit Salemba Medika. 2005

Joshi K, dan Chaturvedi P. Therapeutic efficiency of Centella asiatica (L.) urb. An underutilized green leafy vegetable: An overview. International Journal of Pharma and Bio Sciences. 2013; 4: 135-149.

Kabir AU, Mehdi, D'Costa NM, Akhter F, Ahmed A, Hannan JMA. Anti-Hyperglycemic Activity of Centella asiatica is Partly Mediated by Carbohydrase Inhibition and Glucose-Fiber Binding. BMC Complementary \& Alternative Medicine. 2014 ; 14 (31) : 1-14 
Kumar MHV, Gupta YK. Effect Of Centella Asiatica On Cognition And Oxidative Stress In An Intracerebroventricular Streptozotocin Model Of Alzheimer's Disease In Rats. Clinical and Experimental Pharmacology and Physiology . 2003; 30 :336-342

Levi PAA. 2015. Keripik Daun Pegagan yang Sarat Khasiat. http://www.kompasiana.com/purwanti_asih_anna_levi/keripik-daun-pegagan-yangsarat-khasiat_54f36410745513972b6c7380. (4 Maret 2019).

Lima IFP, Juliano DDL, Vanete TS, José LP, Carlos RS, Development of an Innovative Nutraceutical Fermented Beverage from Herbal Mate (Ilex paraguariensis A.St.-Hil.) Extract. International Journal of Molecular Sciences. 2012, 13, 788-800; doi:10.3390/ijms13010788. www.mdpi.com/journal/ijms

Mahyiddin Z. Inventarisasi Masakan Tradisional Spesifik Aceh Dalam Menu Keluarga di Kecamatan Ingin Jaya Kabupaten Aceh Besar. Prosiding Seminar Nasional BOSARIS II: Kreasi Inovatif Budaya Nusantara. 2014: 116-122.

Marshall RT. Standar Methods for the Examination of Dairy Product. American Public Health Association. Washington DC.1992.

Panghal A, Kiran V, Vikas K, Sanju BD, Yogesh G, Navnidhi C. Development of Probiotic Beetroot Drink. Current Research in Nutrition and Food Science. Vol. 5, No. (3) 2017, Pg. 257-262. Journal Website:www.foodandnutritionjournal.org

Pramono S. Profil Kromatografi Ekstrak Herba Pegagan Yang Berefek Antihipertensi. Bul. Warta Tumbuhan Obat Indonesia I. 1992; (2): 37 - 39.

Rachmawati F, Nuria MC, Sumantri. 2011. Uji Aktivitas Antibakteri Fraksi Kloroform Ekstrak Etanol Antanan (Centella asiatica (L) Urb) Serta Identifikasi Senyawa Aktifnya. Prosiding Seminar nasional Peranan dan Kontribusi Herbal dalam Penyakit Degeneratif Fakultas farmasi, Universitas Wahid Hasyim. Semarang. 2011 : 7- 13.

Rahman MMd, Sayeed SMd, Md. Haque AMd, Hassan M,Islam SMA. Phytochemical Screening, Antioxidant, Anti-Alzheimer, and Anti-diabetic Activities of Centella asiatica, J. Nat. Prod. Plant Resour.2011; 2 (4) : 504-511.

Rahman S, Jamal MAHM, Parvin Amd, Al-Mamun M, M. Islam R. Antidiabetic Activity of Centella asiatica (L.) Urbana in Alloxan Induced Type 1 Diabetic Model Rats. J. bio-sci.2011a ; 19 : 23-27.

Robinson RK, BattCA, Patel PD. editors. Enciclopedia of Food Microbiology. Academic Press. 1999.

Rusmarilin $\mathrm{H}$, Nurhasanah, RY Andayani. Soy-yamgurt probiotic drink as a natural potential of antioxidant. International Conference on Agriculture, Environment, and Food Security IOP Publishing. IOP Conf. Series: Earth and Environmental Science 122 (2018) 012087 doi:10.1088/1755-1315/122/1/012087

Setioningsih E, SetyaningsihR, SusilowatiA. Pembuatan Minuman Probiotik dari Susu Kedelai dengan Inokulum Lactobacillus casei, Lactobacillus plantarum, dan Lactobacillus acidophilus. Jurnal Bioteknologi. 2004; 1(1) : 1-6.

Shurtleff W, Aoyagi A. The Book of Tofu : Tofu and Soymilk Production. Vol 11. The Soybean Center : Lafayette, USA. 1984.

Udoh, DI, Asamudo NU, Bala DN, Enwongo O. Inhibitory Effect of Varying Concentrations of Leaves' Extracts of Centella asiatica (Gotu Kola) on Some Microorganisms of Medicinel Importance. International Journal Chemical, Environmental and Pharmaceutical Research. $2012 ; 3$ (2) : $142-148$.

Volk W. Mikrobiologi Dasar. Diterjemahkan oleh Soenartono Adisoemarto. Jakarta: Erlangga. 1984

Wanita YP, Kobarsih M, Cahyaningrum N. Sifat Fisik Yogurt Sawo (Achras zapota). Prosiding Seminar Nasional Inovasi Teknologi Pertanian. Balai Besar Pengkajian dan 
Pengembangan Teknologi Pertanian. Badan Penelitian dan Pengembangan Pertanian Kementerian Pertanian Banjarbaru. 2017: 1561-1567

Winarno FG. Kimia Pangan dan Gizi. Jakarta: PT Gramedia Pustaka Utama. 2003.

Zainuddin. Pengaruh Konsentrasi Starter dan Lama Fermentasi terhadap Mutu Yoghurt Sari Kedelai. Jurnal Agrina. 2014; 01(01): 14-22. 